\title{
Autosomal Dominant Hypoparathyroidism Associated with Short Stature and Premature Osteoarthritis*
}

\author{
JOHN L. STOCK, ROSALIND S. BROWN, JEFFREY BARON, JAMES A. CODERRE, \\ EDNA MANCILLA, FRANCESCO DE LUCA, KAUSIK RAY, AND \\ MARIA VERONICA MERICQ
}

\begin{abstract}
Divisions of Endocrinology (J.L.S., J.A.C.) and Pediatric Endocrinology/Diabetes (R.S.B.), University of Massachusetts Memorial Health Care and University of Massachusetts Medical School, Worcester, Massachusetts 01605; and the Developmental Endocrinology Branch (J.B., E.M., F.D., M.V.M.), National Institute of Child Health and Human Development, and Metabolic Diseases Branch, National Institute of Diabetes and Digestive and Kidney Disease (K.R.), National Institutes of Health, Bethesda, Maryland 20892
\end{abstract}

\begin{abstract}
Familial hypoparathyroidism is an unusual and genetically heterogeneous group of disorders that may be isolated or may be associated with congenital or acquired abnormalities in other organs or glands. We have evaluated a family with a novel syndrome of autosomal dominant hypoparathyroidism, short stature, and premature osteoarthritis.

A 74-yr-old female (generation I) presented with hypoparathyroidism, a movement disorder secondary to ectopic calcification of the cerebellum and basal ganglia, and a history of knee and hip replacements for osteoarthritis. Two members of generation II and one member of generation III were also documented with hypoparathyroidism, short stature, and premature osteoarthritis evident as early as $11 \mathrm{yr}$.

Because of the known association between autosomal dominant hypoparathyroidism and activating mutations of the calcium-sensing
\end{abstract}

receptor $(\mathrm{CaR})$ gene, further studies were performed. Sequencing of PCR-amplified genomic DNA revealed a leucine to valine substitution at position 616 in the first transmembrane domain of the CaR, which cosegregated with the disorder. However, this amino acid sequence change did not affect the total accumulation of inositol phosphates as a function of extracellular calcium concentrations in transfected HEK-293 cells.

In conclusion, a sequence alteration in the coding region of the $\mathrm{CaR}$ gene was identified, but is not conclusively involved in the etiology of this novel syndrome. The cosegregation of hypoparathyroidism, short stature, and osteoarthritis in this kindred does suggest a genetic abnormality involving a common molecular mechanism in parathyroid, bone, and cartilage. (J Clin Endocrinol Metab 84: 3036-3040, 1999)
$\mathrm{F}^{\mathrm{s}}$ AMILIAL hypoparathyroidism is an unusual and genetically heterogeneous group of disorders of various inheritance patterns that may be associated with other abnormalities such as autoimmune polyglandular disease (1) and congenital syndromes such as DiGeorge, Kenney-Caffey, or Barakat (2). Hypoparathyroidism may also develop as an isolated entity and most often occurs sporadically, but may also occur in a familial pattern. In different families, isolated hypoparathyroidism shows different modes of inheritance [autosomal dominant (3), autosomal recessive (4), or $X$-linked recessive (5)], suggesting that different genetic defects can produce the same phenotype.

Isolated familial hypoparathyroidism has been described as a result of a mutation of the signal peptide-encoding region of the preproparathyroid hormone gene on chromosome $11 p(6)$. It may also be caused by an activating mutation of the calcium receptor $(\mathrm{CaR})$ gene located on chromosome $3 q$ (7-13). This receptor belongs to the G protein-coupled

Received December 21, 1998. Revision received March 4, 1999. Rerevision received May 26, 1999. Accepted June 3, 1999.

Address all correspondence and requests for reprints to: John L. Stock, M.D., Eli Lilly and Company, Lilly Corporate Center, Drop Code 4121, Indianapolis, Indiana 46285. E-mail: jlstock@lilly.com.

* This work was supported in part by a grant from the Roger Robinson Fund at University of Massachusetts Memorial Health Care. Presented in part at the 18th Annual Meeting of the American Society for Bone and Mineral Research, Seattle, WA, September 1996. receptor superfamily. CaR transcripts and protein have been localized to tissues involved in calcium homeostasis including parathyroid, C cells of the thyroid, kidney, bone cells (14), and cartilage (15). Activation of the CaR leads to decreased secretion of PTH and inhibition of renal calcium reabsorption.

We describe a family with a novel syndrome of autosomal dominant hypoparathyroidism associated with short stature and premature osteoarthritis and have investigated the possibility of a mutation in the $\mathrm{CaR}$ gene as the cause of this syndrome.

\section{Subjects and Methods}

Case report (Fig. 1 and Table 1)

Family members in three generations were studied after informed consent was obtained. The study was approved by the NICHHD institutional review board. The index case (patient I-1) presented at age 74 yr with uncontrolled movement of the left leg. Her past medical history was significant for multiple lumbar compression fractures at age $68 \mathrm{yr}$ and hypocalcemia. At age $70 \mathrm{yr}$ the patient underwent bilateral knee and right hip replacements for degenerative arthritis. The physical examination was significant for short stature (16) and frequent, involuntary choreiform movements of the left leg. Additional laboratory studies revealed a serum albumin concentration of $4.0 \mathrm{~g} / \mathrm{dL}$, magnesium of 1.7 $\mathrm{mg} / \mathrm{dL}$, and 25-hydroxyvitamin $\mathrm{D}$ of $33 \mathrm{ng} / \mathrm{mL}$ (normal, 10-55). A computed tomography scan of the head revealed calcification of the cerebellum and basal ganglia bilaterally. Over the following 6 months 


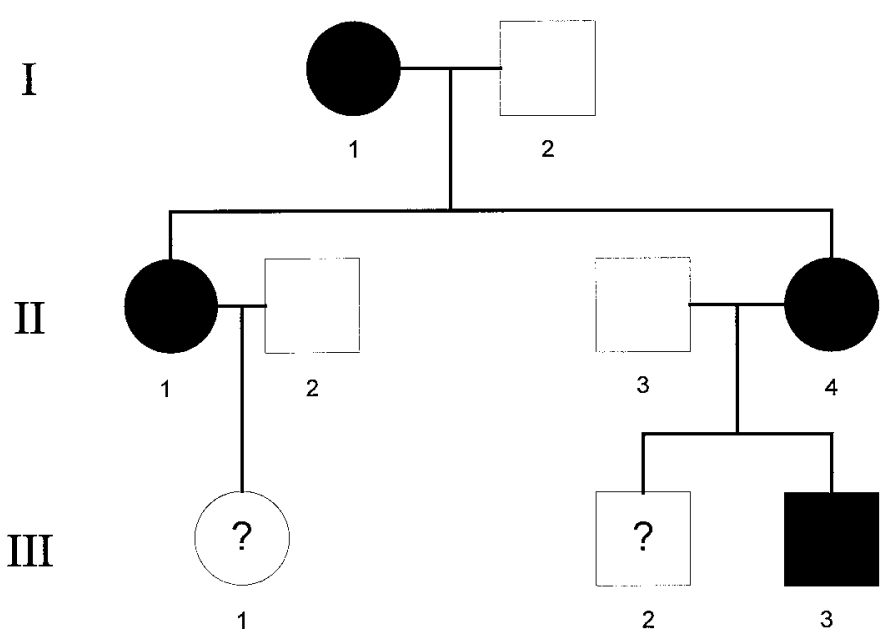

FIG. 1. Pedigree of family with hypoparathyroidism, short stature, and premature osteoarthritis. Darkened symbols represent affected members. Subject III-1 was found to have hypoparathyroidism and short stature at age $24 \mathrm{yr}$ and is possibly affected. Subject III-2 was found to have a low normal serum calcium concentration, short stature, and knee pain and is possibly affected.

she was treated with calcium and vitamin D, and there was dramatic improvement in her movement disorder.

The patient's oldest daughter (II-1) presented at age $45 \mathrm{yr}$ with hypocalcemia and a long history of pain in her knees and feet. Her physical examination was significant only for short stature. The serum magnesium concentration was $1.7 \mathrm{mg} / \mathrm{dL}$, and albumin was $3.9 \mathrm{~g} / \mathrm{dL}$, and she was treated with calcium and vitamin D supplementation. At age $49 \mathrm{yr}$, knee pain increased, and radiographs revealed moderate degenerative arthritis.

Patient II-4 first complained of diffuse aches and pains, particularly of the knees, beginning at age $9 \mathrm{yr}$. At age $31 \mathrm{yr}$ laboratory studies revealed hypocalcemia, a serum magnesium concentration of $1.5 \mathrm{mg} /$ $\mathrm{dL}$, and 25-hydroxyvitamin D of $21 \mathrm{ng} / \mathrm{mL}$. At age $35 \mathrm{yr}$ she underwent the first of several right knee arthroscopic procedures. The physical examination revealed short stature and limitation of right knee flexion. At age $37 \mathrm{yr}$ a right unicondylar knee replacement was performed, and the articular cartilage was found to be roughened and eroded, consistent with degenerative arthritis.

Members of generation III were screened. At age 24 yr subject III-1 was found to have short stature and hypocalcemia, and calcium supplementation was suggested. Subject III-2 had been evaluated for short stature at age $8 \mathrm{yr}$ and was found to have normal GH levels. At age 13 $\mathrm{yr}$ he complained of knee pain, and the serum calcium concentration was $8.6 \mathrm{mg} / \mathrm{dL}$ (normal, 8.4-10.2). Subject III-3 complained of left knee pain at age $11 \mathrm{yr}$, and hypocalcemia was documented. The physical examination revealed short stature, pectus carinatum, a normal knee examination, and a negative Chvostek's sign. Arthroscopy of the left knee was performed, which revealed lateral patellar subluxation and early vascular ingrowth over the hyaline cartilage surface.

\section{DNA amplification and sequence analysis}

Genomic DNA was isolated from white blood cells and exons 1-6 of the CaR were PCR amplified with previously reported primers (17). Screening for mutations was performed by heteroduplex analysis using mutation detection enhancement gels (18). PCR products that showed heteroduplex bands from members III- 2 and III- 3 were sequenced using a fluorescence-based DNA-sequencing system (19).

\section{Restriction analysis}

PCR-amplified genomic DNA was digested with restriction enzyme MaeIII, subjected to electrophoresis through a $6 \%$ polyacrylamide gel, and stained with ethidium bromide.
Site-directed mutagenesis, cell culture, transfection, and preparation of cell membranes

The human CaR complementary DNA (cDNA) inserted into the mutagenesis vector pAlter I (Promega Corp., Madison, WI) was obtained from NPS Pharmaceuticals, Inc. (Salt Lake City, UT). The detected nucleotide change ( $\mathrm{C}$ to $\mathrm{G}$ ) at nucleotide 1846 of exon 6 or other nucleotide changes were introduced into this construct by site-directed mutagenesis using the Altered Sites II system (Promega Corp.). The mutated cDNA were then isolated with restriction enzymes XbaI and HindIII, inserted into the expression vector pcDNAI/Amp (Invitrogen, San Diego, CA), and confirmed by DNA sequencing.

\section{Cell culture and transfection}

HEK-293 cells were cultured in DMEM. The cells were plated in 24-well plates $\left(10^{5}\right.$ cells/well $)$ and transiently transfected with constructs encoding the wild-type and the receptors with nucleotide changes, using $5 \mu \mathrm{L}$ Lipofectamine (Life Technologies, Inc., Gaithersburg, MD) and $0.5 \mu \mathrm{g}$ DNA.

\section{Assessment of cell surface receptor expression by enzyme- linked immunosorbent assay (ELISA)}

Transfected cells were suspended in 1\% BSA-DMEM for $30 \mathrm{~min}$ at 4 $\mathrm{C}$ and then incubated with monoclonal antibody 7F8 $(20 \mu \mathrm{g} / \mathrm{mL})$ for $1 \mathrm{~h}$ at $4 \mathrm{C}$. This antibody was made by immunization with the purified extracellular domain of the human CaR (Goldsmith, P. K., manuscript in preparation). After washing, cells were further incubated with peroxidase-conjugated goat antimouse secondary antibody (Kirkegaarde \& Perry Laboratories, Inc., Gaithersburg, MD; 1:1000 dilution). After washing, peroxidase substrate was added. Absorbance was measured at 405 $\mathrm{nm}$. Four independent transfections were performed for ELISA.

\section{Measurement of phosphoinositides (IPs)}

Forty-eight hours after transfection, HEK-293 cells were labeled with $3 \mu \mathrm{Ci} / \mathrm{mL}$ myo- $\left[{ }^{3} \mathrm{H}\right]$ inositol (New England Biolabs, Inc., Beverly, MA) in DMEM for 16-24 h. Cells were then incubated in PI buffer $(99 \mathrm{mmol} / \mathrm{L}$ $\mathrm{NaCl}, 5 \mathrm{mmol} / \mathrm{L} \mathrm{KCl}, 5.6 \mathrm{mmol} / \mathrm{L}$ glucose, $0.4 \mathrm{mmol} / \mathrm{L} \mathrm{Mg} \mathrm{Cl}$, and 0.5 $\mathrm{mmol} / \mathrm{L} \mathrm{CaCl}_{2}$ ) containing $20 \mathrm{mmol} / \mathrm{L} \mathrm{LiCl}$ for $1 \mathrm{~h}$. Cells were stimulated with the indicated concentrations of $\mathrm{Ca}^{2+}$ (in PI buffer) for $30 \mathrm{~min}$ at $37 \mathrm{C}$. The reactions were terminated with acid-methanol $(167 \mu \mathrm{L} \mathrm{HCl}$ in $120 \mathrm{~mL}$ methanol). Total inositol phosphates were extracted, separated on Dowex AG1-X8 columns as previously described (Berridge, 1983), and counted by liquid scintillation. Nine independent transfections were performed at each $\mathrm{Ca}^{2+}$ concentration for IP measurement.

\section{Statistical analysis}

Results were expressed as the mean \pm SEM. Significance was assessed using an unpaired $t$ test. $P<0.05$ was considered statistically significant.

\section{Results}

\section{DNA sequence analysis}

To screen for sequence alterations in the CaR, individual exons from genomic DNA were PCR amplified and subject to heteroduplex analysis. Possibly affected subject III-2 and definitely affected subject III-3 showed heteroduplex bands in exon 6 (data not shown). Direct sequencing of PCRamplified genomic DNA from possibly affected subject III-2 and definitely affected subject III-3 revealed a heterozygous C to $G$ basepair substitution at position 1846 in exon 6. This change produces a leucine to valine substitution at position 616 in the first transmembrane domain of the receptor (L616V).

Genomic DNA from affected subjects I-1, II-1, II-4, and III-3 and from possibly affected subjects III-1 and III-2 were screened for this possible sequence alteration by restriction 
TABLE 1. Clinical and biochemical features of members of a kindred with autosomal dominant hypoparathyroidism, short stature, and premature osteoarthritis

\begin{tabular}{|c|c|c|c|c|c|c|c|}
\hline $\begin{array}{c}\text { Subject } \\
\text { no. }\end{array}$ & Age (yr) & $\begin{array}{l}\text { Serum } \\
\text { calcium } \\
(\mathrm{mg} / \mathrm{dL})\end{array}$ & $\begin{array}{c}\text { Serum } \\
\text { phosphorus } \\
(\mathrm{mg} / \mathrm{dL})^{a}\end{array}$ & Serum PTH & $\begin{array}{l}\text { Urinary } \\
\text { calcium } \\
(\mathrm{mg} / 24 \mathrm{~h})\end{array}$ & $\mathrm{Ht}(\%)^{b}$ & Osteoarthritis \\
\hline $\mathrm{I}-1$ & 74 & $7.8^{c}$ & 5.6 & $21 \mathrm{pg} / \mathrm{mL}^{d}$ & $133^{e}$ & $<5$ & + \\
\hline II-1 & 45 & $6.0^{f}$ & 3.8 & $27 \mathrm{ng} / \mathrm{dL}^{g}$ & $146,208^{h}$ & $<5$ & + \\
\hline II-4 & 31 & $7.8^{i}$ & 4.0 & $21 \mathrm{pg} / \mathrm{mL}^{d}$ & $54^{e}$ & $<5$ & + \\
\hline III-1 & 24 & $7.9^{f}$ & 4.0 & $31 \mathrm{pmol} / \mathrm{L}^{j}$ & & $<10$ & - \\
\hline III-2 & 13 & $8.6^{c}$ & 6.4 & $140 \mathrm{pg} / \mathrm{mL}^{k}$ & 68 & $<5$ & - \\
\hline III-3 & 11 & $8.1^{c}$ & 5.6 & $110 \mathrm{pg} / \mathrm{mL}^{k}$ & 24 & 5 & + \\
\hline
\end{tabular}

${ }^{a}$ Normal, $2.5-4.5 \mathrm{mg} / \mathrm{dL}$.

${ }^{b}$ Percent 18 yr-old height for adults and percent age-matched height for subjects III-2 and III-3 (16).

${ }^{c}$ Normal, $8.4-10.2 \mathrm{mg} / \mathrm{dL}$.

${ }^{d}$ Normal, $10-65 \mathrm{pg} / \mathrm{mL}$, intact.

${ }^{e}$ While taking calcium and ergocalciferol.

${ }^{f}$ Normal, $8.5-10.5 \mathrm{mg} / \mathrm{dL}$.

${ }^{g}$ Normal, 0-180 ng/dL, C-terminal.

${ }^{h}$ While taking calcium, ergocalciferol, and hydrochlorothiazide/triamterine.

${ }^{i}$ Normal, $9-0-10.6 \mathrm{mg} / \mathrm{dL}$.

${ }^{j}$ Normal, $18-120 \mathrm{pmol} / \mathrm{L}, \mathrm{C}$-terminal.

${ }^{k}$ Normal, $50-340 \mathrm{pg} / \mathrm{mL}$, midregion.

$\begin{array}{lllllllll}1 & 2 & 3 & 4 & 5 & 6 & 7 & 8 & 9\end{array}$

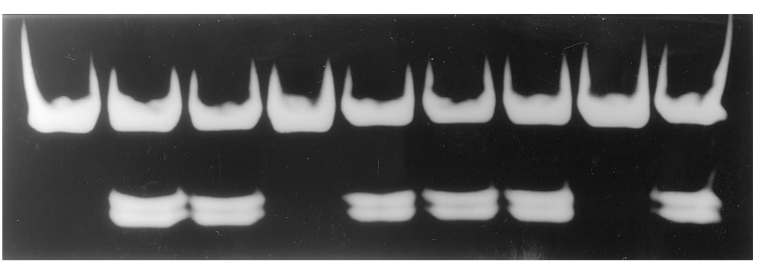

FIG. 2. MaeIII restriction enzyme digest of PCR-amplified exon 6 DNA from family members. MaeIII recognizes a site created by the C1846G basepair substitution in exon 6 . The unaffected family members (I-2, lane 1; II-2, lane 8; II-3, lane 4) show a single band that represents the two wild-type alleles. The affected family members with hypoparathyroidism, short stature, and premature osteoarthritis (I-1, lane 2; II-1, lane 7; II-4, lane 3; III-3, lane 6) all show the wild-type band and two additional fragments that represent the mutant allele cut by MaeIII. Possibly affected family members (III-1, lane 9; III-2, lane 5) also demonstrate the wild-type band and the two additional fragments.

analysis. All of these members were found to have additional fragments representing a possible mutant allele cut by MaeIII (Fig. 2).

\section{Assessment of receptor expression (Table 2)}

Cell surface expression of the L616V construct and wildtype CaRs on the plasma membranes of transfected and control HEK-293 cells was assessed by ELISA. The mean cell surface expression was lower for L616V than for the wildtype receptor.

\section{Functional analysis (Fig. 3 and Table 2)}

After transient transfection with wild-type or possible mutant constructs, HEK-293 cells were exposed to graded $\mathrm{Ca}^{2+}$ concentrations, and IP accumulation was measured. There was no significant difference in the maximal or minimal response to $\mathrm{Ca}^{2+}$. Although there may have been a slight leftward shift in the concentration-response curve for the $\mathrm{L} 616 \mathrm{~V}$ receptor, the decrease in $\mathrm{EC}_{50}$ compared to that for the wild-type receptor did not quite reach statistical significance $(P=0.054)$.

\section{Discussion}

We have described a family with mild hypoparathyroidism associated with short stature and premature osteoarthritis, inherited in an autosomal dominant pattern. To our knowledge, this is the first report of this association. We considered a mutation in the $\mathrm{CaR}$ gene in members of this family in view of recent reports demonstrating gain of function mutations in the extracellular domain of the CaR in families with autosomal dominant hypoparathyroidism (9). Given the report of $\mathrm{CaR}$ expression in human bone cells (14) and in animal articular and growth plate cartilage (15), we also hypothesized that an abnormality in the CaR in bone or cartilage might also contribute to the familial short stature and premature osteoarthritis in this family.

In our study we found a heterozygous $C$ to $G$ basepair substitution at position 1846 in exon 6 that cosegregated with the disorder. This basepair change produced a change in the amino acid sequence of leucine to valine at amino acid position 616. This amino acid sequence change did not affect total accumulation of inositol phosphates as a function of extracellular calcium concentrations in transfected HEK-293 cells.

In the same experiment, we measured the function of the activating mutation F612S, identified in a family with autosomal dominant hypoparathyroidism. The results have been reported previously (12) and serve as a positive control compared to the wild-type results in Table 2. This mutation produced a leftward shift in the concentration-response curve, with a decrease in the $\mathrm{EC}_{50}$ to $2.3 \pm 0.06 \mathrm{mmol} / \mathrm{L}(P<$ $0.001)$ and an increase in the maximum IP accumulation to $42 \pm 3 \times 10^{3} \mathrm{cpm}(P<0.02)$ compared to wild-type values.

However, the cell surface receptor expression in our in vitro system was decreased for L616V compared to wild-type receptors. In the same experiment, the cell surface expression of mutation F612S was also lower than that in wild-type receptors (1.3 \pm 0.6 optical density units), but did not reach 
TABLE 2. Cell surface expression, IP accumulation, and $\mathrm{EC}_{50}$ for wild-type (WT) and patient receptors

\begin{tabular}{lccc}
\hline $\begin{array}{l}\text { Receptor } \\
\text { sequence }\end{array}$ & $\begin{array}{c}\text { ELISA } \\
(\text { OD units })\end{array}$ & $\begin{array}{c}\text { Minimum IP accumulation } \\
\left(0.5 \mathrm{mmol} / \mathrm{L} \mathrm{Ca}^{2+} ; 10^{3} \mathrm{cpm}\right)\end{array}$ & $\begin{array}{c}\text { Maximum IP accumulation } \\
\left(8 \mathrm{mmol} / \mathrm{L} \mathrm{Ca} \mathrm{Ca}^{2+} ; 0^{3} \mathrm{cpm}\right)\end{array}$ \\
\hline WT & $3.7 \pm 0.1$ & $3.6 \pm 0.6$ & $33 \pm 2$ \\
L616V & $1.8 \pm 0.1^{a}$ & $4.4 \pm 0.5$ & $3.3 \pm 0.2$ \\
$(\mathrm{mmol} / \mathrm{L})$
\end{tabular}

Values are the mean \pm SEM. ELISA values reflect cell surface CaR expression $(0.4 \pm 0.1$ for untransfected cells $)$.

${ }^{a} P<0.001$ compared to WT.

FIG. 3. $\mathrm{Ca}^{2+}$-evoked accumulation of IP in HEK-293 cells transiently transfected with wild-type or possibly mutant CaR cDNA. Transfected HEK-293 cells were incubated with myo- $\left[{ }^{3} \mathrm{H}\right] \mathrm{i}-$ nositol and then stimulated with the indicated $\mathrm{Ca}^{2+}$ concentration for 30 min. Total inositol phosphates were isolated and counted by liquid scintillation. Each data point represents the mean \pm SEM of nine independent transfections.

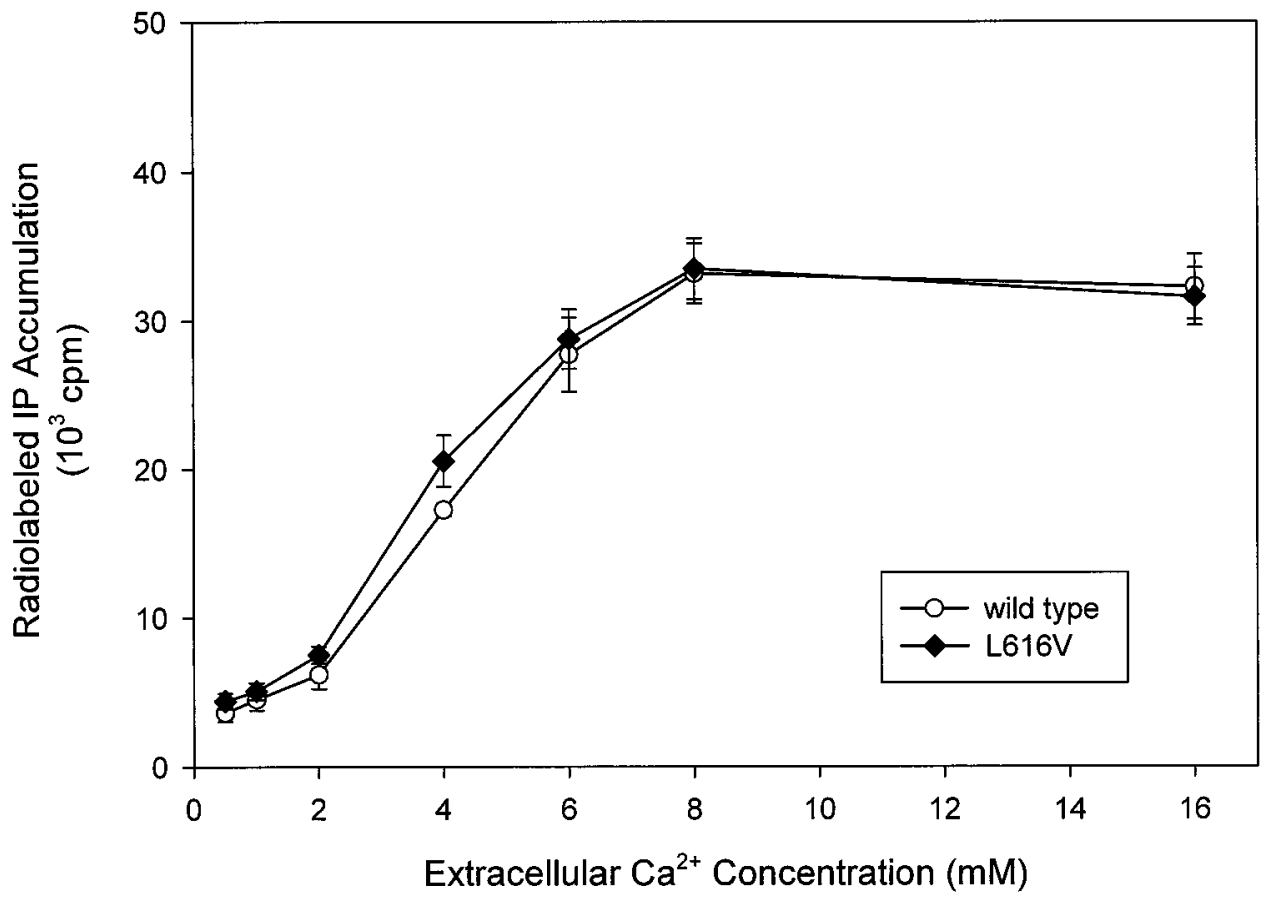

statistical significance $(P=0.06)(12)$. The signal transduction activity per receptor may be higher for L616V than for wildtype receptors. If the cell surface expression of the L616V receptor in vivo was similar to that of the wild-type receptor, then this possibly increased activity per receptor might account for the phenotype. Alternatively, a mutation in the promoter or in other regulatory genes for the expression of the CaR cannot be ruled out. It is also possible that this sequence alteration may affect another signal transduction pathway or that the causative mutation lies in a nearby gene. There are several families with autosomal dominant hypoparathyroidism in whom $\mathrm{CaR}$ mutations have not been documented despite extensive analysis $(8,9)$.

A clinical issue to be considered in caring for members of this family is surveillance for ectopic calcifications, which have had significant effects on family member I-1 despite the mild nature of her disease. Basal ganglia calcifications and subsequent movement disorders have been described in mild chronic hypoparathyroidism (20). Periodic brain imaging studies might be performed in these patients. Whether treatment of affected members to raise their serum calcium concentrations to low normal levels will be of benefit in preventing or delaying ectopic calcifications remains to be elucidated. Hypercalciuria, usually a concern in the treatment of hypoparathyroidism, was not demonstrated in this family. Hypercalciuria has been found in families with doc- umented mutations of the CaR, probably related to a decrease in the tubular reabsorption of calcium (10).

The description of this family extends previous observations that familial hypoparathyroidism is a heterogeneous disorder. A sequence alteration in the coding region of the $\mathrm{CaR}$ gene was identified and cosegregates with the phenotype, suggesting a causal relationship. However, the expression data and functional analysis do not conclusively demonstrate that this sequence alteration activates the receptor. The association of hypoparathyroidism, short stature, and osteoarthritis in this kindred does suggest a genetic abnormality involving a common molecular mechanism in parathyroid, bone, and cartilage.

\section{Acknowledgments}

We thank the family members for their cooperation; Drs. Anne Sigsbee and Robert Millstein for their assistance in evaluating the family. Dr. Allen Spiegel for facilitating expression studies; Drs. Meryl LeBoff, Michael Levine, and Edward Brown for their helpful discussions; and Ms. Carol Gaylord for expert secretarial assistance.

\section{References}

1. Aaltonen J, Björses P, Sandkuijl L, Perheentupa J, Peltonen L. 1994 An autosomal locus causing autoimmune disease: autoimmune polyglandular disease type 1 assigned chromosome 21. Nat Genet. 8:83-87.

2. Thakker RV. 1994 Molecular genetics of hypoparathyroidism. In: Bilezikian 
JP, Levine MA, Marcus R, eds. The parathyroids. New York: Raven Press; 765-779.

3. Ahn TG, Antonarakis SE, Kronenberg HM, et al. 1986 Familial isolated hypoparathyroidism: a molecular genetic analysis of 8 families with 23 affected persons. Medicine. 65:73-81.

4. Parkinson DB, Thakker RV. 1992 A donor splice site mutation in the parathyroid hormone gene is associated with autosomal recessive hypoparathyroidism. Nat Genet. 1:149-152.

5. Thakker RV, Davies KE, Whyte MP, Wooding C, O'Riordan JLH. 1990 Mapping the gene causing $X$-linked recessive idiopathic hypoparathyroidism to Xq26-Xq27 by linkage studies. J Clin Invest. 86:40-45.

6. Arnold A, Horst SA, Gardella TJ, Baba H, Levine MA, Kronenberg HM. 1990 Mutation of the signal peptide-encoded region of the preproparathyroid hormone gene in familial isolated hypoparathyroidism. J Clin Invest. 86:1084-1087.

7. Brown EM, Gamba G, Riccardi D, et al. 1993 Cloning and characterization of an extracellular $\mathrm{Ca}^{2+}$ sensing receptor from bovine parathyroid. Nature. 366:575-580.

8. Pollack MR, Brown EM, Estep ML, et al. 1994 Autosomal dominant hypocalcemia caused by a $\mathrm{Ca}^{2+}$-sensing receptor gene mutation. Nat Genet. 8:303-307.

9. Pearce SHS, Williamson C, Kifor O, et al. 1996 A familial syndrome of hypocalcemia with hypercalciuria due to mutations in the calcium-sensing receptor. N Engl J Med. 335:1115-1122.

10. Baron J, Winer KK, Yanovski JA, et al. 1996 Mutations in the $\mathrm{Ca}^{2+}$-sensing receptor gene cause autosomal dominant and sporadic hypoparathyroidism. Hum Mol Genet. 5:601-606.

11. De Luca F, Ray K, Mancilla EE, et al. 1997 Sporadic hypoparathyroidism caused by de novo gain-of-function mutations of the $\mathrm{Ca}^{2+}$-sensing receptor. J Clin Endocrinol Metab. 82:2710-2715.

12. Mancilla EE, De Luca F, Ray K, Winer KK, Fan G-F, Baron J. 1997 A Ca ${ }^{2+}$ sensing receptor mutation causes hypoparathyrodism by increasing receptor sensitivity to $\mathrm{Ca}^{2+}$ and maximal signal transduction. Pediatr Res. 42:443-447.

13. Mancilla EE, De Luca F, Baron J. 1998 Activating mutations of the $\mathrm{Ca}^{2+}$ sensing receptor. Mol Genet Metab. 64:198-204.

14. House MG, Kohlmeier L, Chattopadhyay N, et al. 1997 Expression of an extracellular calcium-sensing receptor in human and mouse bone marrow cells. J Bone Miner Res. 12:1959-1970.

15. Chang W, Tu C-L, Chen T-H, Miller S, Strewler G, Shoback D. Ca ${ }^{2+}$ receptor expression in cartilage and the effects of extracellular $\mathrm{Ca}^{2+}$ on nodule formation in cultured chondrogenic cells. Proc of the 79th Annual Meet of The Endocrine Soc. 1997; 103.

16. Hamill PVV, Drizd TA, Johnson CL, et al. 1979 Physical growth: National Center for Health Statistics percentiles. Am J Clin Nutr. 32:607-629.

17. Pollak MR, Brown EM, Chou YW, et al. 1993 Mutations in the human $\mathrm{Ca}^{2+}$ sensing receptor gene cause familial hypocalcemic hypercalcemia and neonatal severe hyperparathyroidism. Cell. 75:1297-1303.

18. White MB, Carvalho M, Derse D, O'Brien SJ, Dean M. 1992 Detecting single base substitutions as heteroduplex polymorphisms. Genomics. 12:301-306.

19. Smith LM, Sanders JZ, Kaiser RJ, et al. 1986 Fluorescence detection in automated DNA sequence analysis. Nature. 321:674-679.

20. Tambyah PA, Ony BKC, Lee KO. 1993 Reversible Parkinsonism and asymptomatic hypocalcemia with basal ganglia calcifications from hypoparathyroidism 26 years after thyroid surgery. Am J Med. 94:444-445. 